\title{
Marine Parks for Coastal Cities: A concept for enhanced community well- being, prosperity and sustainable city living
}

\author{
S.J. Pittmana, ${ }^{a, b^{\star}}$, L.D. Rodwella,c, R.J. Shellock ${ }^{a, e, f}$, M. Williams ${ }^{a, d}$, M.J. Attrilla,h, J. Bedford ${ }^{a, h}$, K. Curry, \\ S. Fletcheri , S.C. Galla,g, , J. Lowther ${ }^{a, g}$, A. McQuatters-Gollop ${ }^{a, h}$, K.L. Moseley ${ }^{b, k, l}$, S.E. Rees ${ }^{a, h}$
}

\begin{abstract}
a Marine and Coastal Policy Research Unit, University of Plymouth, Plymouth, PL4 8AA, United Kingdom
b Seascape Research CIC, Plymouth, United Kingdom

c School of Geography, Earth and Environmental Sciences, Faculty of Science and Engineering, University of

Plymouth, Plymouth, PL4 8AA, United Kingdom

${ }^{d}$ Devon \& Severn Inshore Fisheries and Conservation Authority, United Kingdom

e Plymouth Marine Laboratory, Prospect Place, Plymouth, PL1 3DH, United Kingdom

${ }^{f}$ European Centre for Environment and Human Health (ECEHH), University of Exeter Medical School, Truro, United Kingdom

g School of Law, Criminology and Government, Faculty of Business, University of Plymouth, Plymouth, PL4 8AA, United Kingdom

h School of Biological and Marine Science, Faculty of Science and Engineering, University of Plymouth, Plymouth, PL4 8AA, United Kingdom

i United Nations Environment Program World Conservation Monitoring Centre (UNEP-WCMC), 219 Huntingdon

Road, Cambridge, CB3 ODL, United Kingdom

i Strategic Planning and Infrastructure, Plymouth City Council, Ballard House, West Hoe Road

Plymouth, PL1 3BJ, United Kingdom

k Ecology \& Spirituality, Schumacher College, Dartington, TQ9 6EA, United Kingdom

I University of Wales, Trinity St. David, Lampeter Campus, Ceredigion SA48 7ED, United Kingdom
\end{abstract}

*Corresponding author: Tel.: +44 1752227153

sjpittman@gmail.com

13 Haddington Road, Plymouth, PL2 1RP

Declarations of interest: none 


\section{Abstract}

Coastal cities continue to experience rapid urbanisation and population growth worldwide, linked to the diverse economic and social benefits flowing from proximity to the sea. Growing concern over human impacts upon coastal waters and global strategic goals for healthier cities requires that coastal cities develop innovative ways to inspire and empower communities to embrace and cherish city seascapes. Coastal city communities have much to gain from a healthier relationship with the sea. This paper proposes a collaborative community-led marine park concept that celebrates a city's connection to the marine environment, enhances sustainable economic prosperity and enables communities to participate in activities that deepen understanding, value, care and enjoyment of the city seascape. A city marine park (CMP) is not a marine protected area because it does not have biodiversity and heritage protection or ecosystem governance as a primary goal and does not aim to restrict human activities. A CMP enables city communities to collaborate towards a shared vision of elevated status and value for the city seascape. A CMP considers socio-economic and geographical context, including land-sea connectivity, and is integrated within a coastal city's strategic urban planning. This paper highlights core themes of a CMP and the diverse and wide-ranging benefits from coordinated activities that better connect the city community with its seascape. If co-created with the coastal city community, a CMP will form an enduring spatial nexus for progress toward healthy cities addressing multiple interlinked global sustainable development goals.

Keywords: marine park; coastal cities; city seascape; blue health; blue urbanism; sustainable development goals

\section{Introduction}

The coastal zone is a place of increasingly intense human interest and activity because of diverse and abundant natural resources, navigable waters, maritime infrastructure and trade routes, and opportunities for recreation and tourism. Half of the global population now lives within $100 \mathrm{~km}$ of the coast, with population density projected to increase from 115 people km${ }^{2}$ by 2025 to 134 people $\mathrm{km}^{-2}$ by 2050 [1]. In 2009, 67\% of the world's megacities (>10 million inhabitants) were coastal [2]. With the knowledge that the world's population is projected (with a $95 \%$ probability) to reach between 9.4 and 10.2 billion in 2050 and between 9.6 and 13.2 billion in 2100 [3], and with $70 \%$ of humankind living in cities, the global sustainability movement has recognised that cities occupy a pivotal position in the transition towards sustainable development [4]. The United Nations New Urban Agenda (NUA) has firmly placed urbanisation at the forefront of international development policy focusing on three transformative commitments; social inclusion and ending poverty; sustainable and inclusive 
urban prosperity and environmentally sustainable and resilient urban development [5]. Despite the strategic importance of coastal cities to achieving sustainable development goals (SDGs) surprisingly little attention has been directed at finding innovative ways to integrate the seascape into city-wide initiatives to achieve healthy, prosperous and sustainable coastal cities (Box 1).

\section{Box 1. Concepts relevant to a city marine park \\ What is a healthy city? \\ A healthy city is one that continually creates and improves its physical and social environments and expands the community resources that enable people to mutually support each other in performing all the functions of life and developing to their maximum potential (WHO Healthy Cities Project [6]). The Healthy Cities approach includes a strong focus on empowerment and participation, being concerned with individuals' ability and autonomy to live a healthy life [7].}

\section{What is a prosperous city?}

A prosperous city is an inclusive one that provides spaces for social engagement; recreation, social and economic development of vulnerable groups; and fosters social cohesion through the provision of adequate and well-designed public spaces (SDG 11 Synthesis Report [4]). By 2030, UN Target 11.7 challenges cities worldwide to provide universal access to safe, inclusive and accessible, green and public spaces, particularly for women and children, older persons and persons with disabilities.

\section{What is a sustainable city?}

A sustainable city achieves a dynamic balance among economic, environmental and socio-cultural development goals, framed within a local governance system characterized by deep citizen involvement and inclusiveness [8]. For coastal cities, sustainability objectives must include the city seascape.

\section{What is a city seascape?}

We define a city seascape as the marine and coastal space (above and below water) that most influences the city and is most influenced by the city. The size and shape of this seascape space will be unique to each coastal city. The attributes that define a city seascape will likely be holistic and include places and features with cultural, social, economic, geological and biological significance and may extend inland from the coast to encompass the tidal reaches of rivers and wetlands.

\section{What is a blue space?}

Blue space has been defined as all 'health-enabling places and spaces, where water is at the centre of a range of environments with identifiable potential for the promotion of human wellbeing' [9]. Blue space is a component of the city seascape with therapeutic benefits varying through multi-dimensional space.

Cities, and urbanisation in general, are associated with a wide range of negative impacts to public health and community well-being that have led to a renewed recognition of the importance of natural infrastructure including the need for health-promoting public spaces [1012]. Analogous to green public spaces, 'blue space' (Box 1) is increasingly recognised by health experts, urban ecologists and planners focused on the challenge of achieving healthier sustainable city living [13-17]. The city seascape provides diverse potential for enhancing blue space for its citizens, yet many coastal cities have undervalued the city seascape as a health promoter, particularly where industrial uses dominate. New holistic thinking on the role of the 
marine space and the development of healthy interconnected land-sea urban ecosystems has improved urban functionality and quality of life in coastal cities [18,19].

This paper introduces the concept of a city marine park (CMP) that is more closely linked to urban social policy initiatives such as increasing access to green and blue natural infrastructure for community health and well-being than it is to the conventional place-based approach of marine protected areas (MPAs). With a focus on deepening and broadening positive connections between city and sea, the CMP concept has great potential for building a more inclusive marine citizenship [20] in coastal cities with scope to both enhance the flow of a wide range of existing socio-economic and environmental benefits and create new benefits and beneficiaries.

A CMP functions as a network of cross-sectoral partnerships with strategic investments operating to achieve a shared vision of sustainable use, improved equality of access, and the restoration and maintenance of healthy city seascapes critical to progress towards healthy, prosperous and sustainable coastal cities. A CMP recognises the rich economic and social capital and propensity for innovative solutions to urban problems that are contained within cities [21, 22]. A CMP recognises the potential for broader inclusivity emerging from a shift in natural resource governance and policy setting that has been occurring globally from primarily top-down state-led governance to more participatory community-based and multi-level collaborative governance [13-26]. As such, a CMP will likely grow organically from a city's individual context, civic needs and ambition. Furthermore, a ground swell of societal awareness and concern for marine ecosystem condition and for coastal community vulnerabilities associated with environmental change is occurring globally [27, 28]. From this concern, an 'blue urban agenda' is beginning to emerge, initially fuelled by the threat to urban waterfronts from sea-level rise in Small Island Developing States, but with broader implications also for global sustainable development $[29,30]$. Crucially, the blue urban agenda recognises the interplay between land and sea; where the sea influences city living, and cities are drivers of change beyond their administrative boundaries.

This paper first provides an overview of the community-centred concept of a CMP and explains how it differs from a statutory designation such as a marine protected area. Subsequent sections highlight the potential of a CMP to function as a spatial nexus for addressing multiple inter-linked sustainable development goals (SDGs) for coastal cities with diverse positive long-term consequences for healthy and prosperous coastal city living. The final section considers some of the actions required for implementation. 


\section{Overview of the City Marine Park (CMP) concept}

This section offers a definition and a generic conceptual model for a CMP to highlight the intention, the spirit of a CMP, and some of the core principles and possible benefits (Fig. 1) but does not attempt to prescribe a set of eligibility criteria or formal guidelines.

A CMP is: an ocean and coastal space defined by collective local knowledge and recognised for its special importance for city community health, well-being and heritage, with the intention of encouraging greater prosperity and responsible enjoyment and deepening knowledge, appreciation and care for the city seascape and the broader Earth system.

\section{City Marine Park (CMP)}

An ocean and coastal space defined by collective local knowledge and recognised for its special importance for city community health, well-being and heritage, with the intention of encouraging greater prosperity and responsible enjoyment, deepening knowledge, appreciation and care for the city seascape and the broader Earth system.

A coordinated network to enhance:

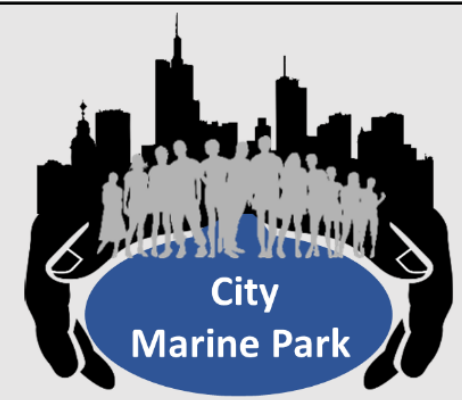

inting Equality of access and social inclusion in park activities

6 (O) Marine literacy and marine citizenship

(3) Business partnerships for positive social and environmental impacts Wh Place identity, place-branding - $\square$, Community health and well-being

血管就 Celebration of marine and Joined-up inclusive stewardship maritime heritage

Fig. 1. Definition and key objectives of a city marine park (CMP).

\subsection{A CMP is an enabler of inclusive civic participation with the city seascape.}

A CMP focuses strongly on creating enabling conditions for enhanced community appreciation, participation and enjoyment of the marine park space much like the more familiar function of a terrestrial urban community park. Broader positive socio-ecological objectives can be met without additional legislation where a desire for healthy ecosystems is linked to sustainable use through activities that nurture local community knowledge, value and enjoyment of the marine space and a commitment to care for and restore good ecosystem 
status. This approach is consistent with objectives for improving marine literacy and marine citizenship [20, 24].

\subsection{A CMP is integrated into city planning and policy.}

A CMP is a place-based designation that emerges as a city planning and policy tool used for local community benefit and suited to coastal cities with diverse marine activities that are closely linked to socio-economic prosperity and community sense of place. The CMP approach must be holistic with the primary objectives focused on nurturing greater community involvement in caring for and safeguarding long-term health and integrity of the CMP consistent with sustainable development. To achieve this, the CMP must be a catalyst for proenvironmental behaviour [24], promoting optimism for the future and actively supporting city communities and commerce to work towards enhanced health and prosperity. As a local community-led designation process, however, the specific objectives will vary by region depending on the local community needs and aspirations and the composition of the steering body. The reference to 'collective local knowledge' in the CMP definition provides opportunity for the CMP to be crafted to fit the needs and aspirations of the host city by considering the unique history and local heterogeneity in cultural, socio-economic, geographical, and ecological characteristics. Unlike most protected area designations, qualification for a CMP is not dependent on the condition of the city seascape, it's habitat and species diversity and does not hinge on the presence of any special features of conservation value. From this inclusive perspective, all coastal cities, regardless of size, location and condition of the city seascape, are suitable and eligible for a CMP.

\subsection{CMP social mechanism and objectives}

A core aspiration of the CMP vision is to create a positive feedback circle (CMP circle) (Fig. 2) which seeks to build and strengthen positive relationships between people and the CMP through initiatives (e.g., educational, recreational, commercial), campaigns and commerce that will enhance opportunity for understanding, value, enjoyment and care in the community for the features and character of the CMP. The process recognises, however, that there are significant barriers to moving through the stages described by the CMP circle. For instance, transition from understanding and experiencing of the CMP will not inevitably lead to increased value and pro-environmental behaviour without interventions (e.g., education, incentivisation, training and nudges) and policies (e.g., environmental and social planning, communication and marketing) [42-44], nor will enjoyment necessarily lead to a desire for greater understanding. Many factors influence pro-environmental behaviour and there may be a considerable gap between the value attributed to marine and coastal environments and the level of action taken to preserve them, particularly in relation to behaviours that require a 
higher investment of time or money (e.g., volunteering on marine conservation projects, taking part in marine planning and switching to renewable energy) [45,46]. Understanding and overcoming the barriers to access and strengthening the connections between citizens and the seascape will shape the character of the CMP.

Nevertheless, positive examples of the potential of enhanced experience and understanding leading to behaviour change and policy change do exist. For example, addressing the plastic pollution in the ocean is now a global movement of ocean care generated by connecting understanding and value which resulted in action at individual, community, national and trans-national levels of governance [47]. Pro-environmental behaviour change, however, is likely to be more lasting and meaningful if understanding is developed through direct experience with the city seascape (school trips, citizen science projects, visits to the beach) [48].

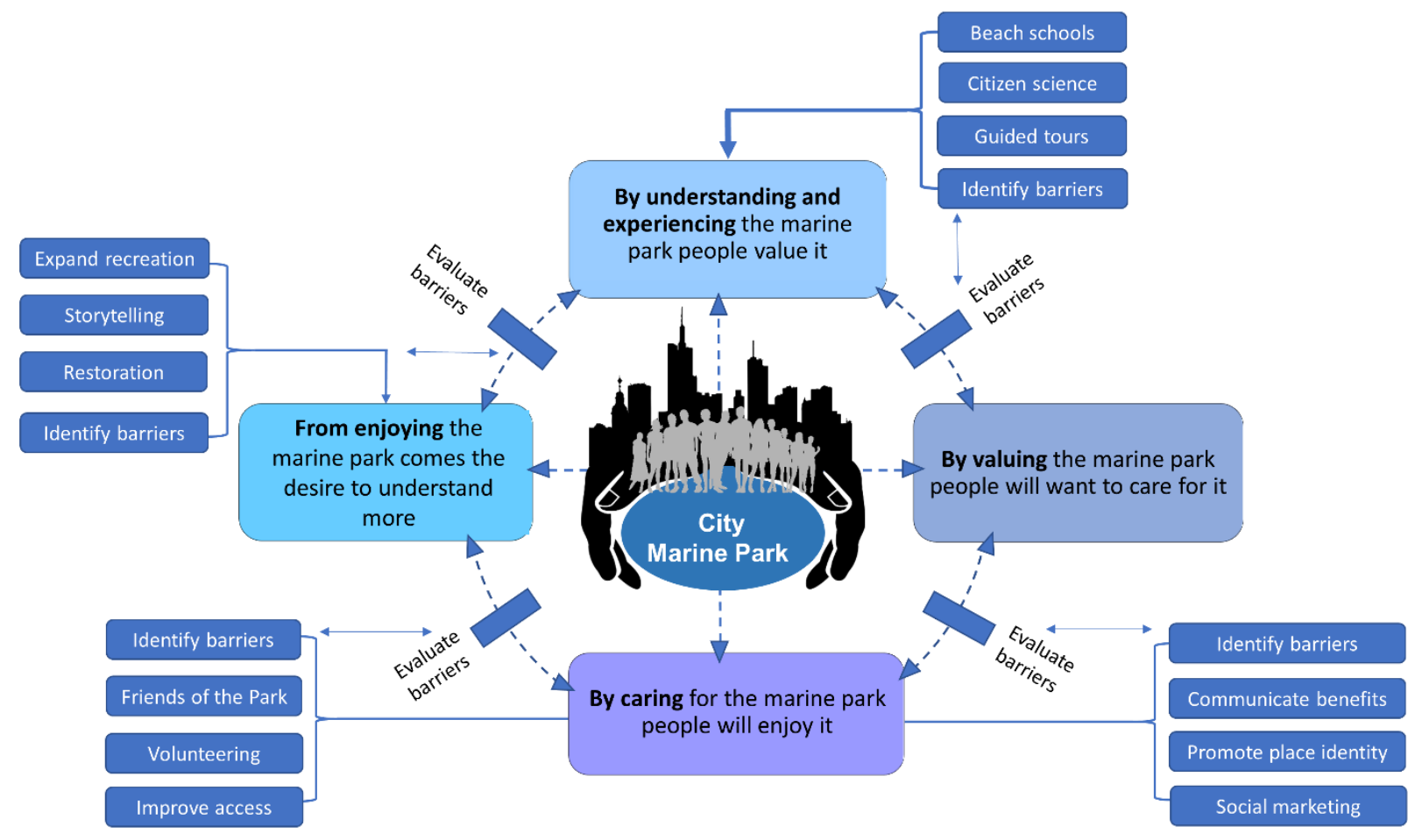

Fig. 2. The city marine park (CMP) model embodies a positive feedback circle linking experience and understanding to greater value, care and enjoyment. Some examples of project activities designed to target one or several of the four stages to perpetuate a flourishing network of activities to grow deeper emotional connection and pride in the marine park.

\section{4. $A C M P$ is not a marine protected area (MPA)}

A CMP is not a new class of statutory marine protected area. Most ocean spaces referred to as 'marine parks' exist as statutory place-based protected areas designed for multiple uses (e.g., Great Barrier Reef Marine Park, Australia), with some designated as no-take MPAs (e.g., Malindi Marine National Park, Kenya) commonly managed by central government. In contrast, 
the CMP concept purposefully exists outside of the conventional MPA framework (i.e., IUCN Protected Area Management Categories [31,32] because the objectives and definition do not directly manage to protect or conserve nature. A CMP does not implement or replace existing protected areas, but as a non-statutory and purely administrative entity, can through strengthening participation and focusing on interlinked socio-ecological objectives, help to coordinate complementary activities that address some of the well-documented social shortcomings of existing exclusionary place-based approaches in mainstream conservation [33-37]. Although the CMP primarily addresses a broad scope of social issues, the initiative could be designed as an 'other effective area-based conservation measures' (OECMs) and contribute to global area targets for marine protection as required by the Convention on Biological Diversity Aichi Target 11 [38] particularly if the CMP applies conservation science design criteria and intends to be accountable for measurable outcomes for conservation of biodiversity $[39,40]$.

Many coastal cities already have statutory designations in place either for conservation purposes (habitats, species, geology, cultural heritage) or de-facto protection from areas of restricted access or activity (e.g., military zones, hazardous areas, navigation routes, renewable energy installations). Since a CMP is not new protection, it should also never be considered a 'paper park', a term often applied to legally protected areas that fail to adequately protect ecosystems by halting degradation [41]. Likewise, a CMP does not attempt to replace or consolidate existing protected area designations, but instead can function as an umbrella entity existing within a very different cross-sectoral framework that is well-placed to assist community engagement in support of existing protected area efforts. This non-statutory approach is intended to avoid conflicts and anxiety that can emerge in response to imposed regulations on park use and access and instead focuses investments on enhancing positive healthy relationships, innovative solutions for sustainable development and inclusive local participation.

\section{Benefits of a City Marine Park}

\subsection{CMP improves equality of access and social inclusion in the city seascape}

Benefits flowing from a CMP will not be homogeneous or universal across the city, therefore examining and securing equality of opportunity and utilisation in the CMP will be an ongoing priority. To help address universal access and increased social inclusivity, equity and justice, the CMP should promote broad community participation and strive to overcome barriers to social and physical accessibility and participation in all CMP focused activities [49].

Interest in participation will vary. Understanding how the public and different groups of citizens perceive, experience and value the marine environment is important guiding 
information for a CMP that will help understand the potential for participation. An early activity for cities interested in initiating a CMP will be to carry out Public Perception Research (PPR) to understand people's relationship with the city seascape and determine the how, why and where questions of coastal space use, understand people-seascape connections and to enquire about ways the city seascape could better enhance their lives. What would your relationship with the city seascape look like if you had the power to make it any way you wanted? A visioning exercise helps co-create and shape common goals and consider alternative futures.

Projects could aim to inspire citizens least likely to visit the city seascape (for example those living in socio-economic deprivation and older adults with poor health, disability, not working) [50] and examine obstacles to access that may hinder the opportunity for a positive experience of the CMP space (e.g., litter, and safety; [51,52]. For instance, in the UK, although the seaside is typically a more socially inclusive recreation area compared with inland green spaces (i.e., woodlands) [56], 18\% of children surveyed had never stepped foot on a UK beach [57].

Strengthening public access to safe and restorative places within the city seascape is an important activity in achieving the goal of a healthy coastal city [53]. As such, a CMP should support networks and partnerships to improve inclusive accessibility and enjoyment for people with a range of different abilities and needs [54]. For example, collaborative efforts between the Tourist Board of Greece and a disabled people's association designed infrastructure that provided safe access to beaches and the sea and allowed some people their first swim in the sea [55]. A CMP must review best practice in achieving equality of access and improving social inclusion in participation in CMP activities not only for waterfront communities, but also for city communities more distant from the water's edge.

Urban planning and architecture are a key part of the solution to address many of the barriers to access and enjoyment of the city seascape. In some coastal cities, especially historic seaports, waterfront regeneration has focused on increasing connectivity between people and the seascape through urban design interventions. Successful designs to increase the accessibility and positive experience of the city seascape vary in scale from small structural modification (i.e., urban acupuncture) to enhance fascination and sense of place to major waterfront regeneration projects such as the city of Baltimore's Inner Harbor revitalisation project that transformed the waterfront and established a new city-sea connectivity generating strong social, economic, cultural, and recreational impacts [58]. A community-centred CMP would play a key role in re-evaluating the waterfront design and examine opportunities to modify the structure in ways that better connect people with the city seascape. 


\subsection{CMP for enhancing ecological understanding and stewardship of the city seascape}

The local city community, the people with most to gain from a healthy, vibrant and prosperous city seascape, should play a central role in the responsible stewardship and future condition of their city seascape. Greater public understanding and participation in the marine environment can lead to long-term stewardship benefits particularly where information connects directly to marine citizenship and results in recognition of interdependence, the consequences of consumer choice, and shared responsibility [20]. If a CMP is to add value to existing local efforts in marine stewardship, including support for statutory place-based conservation designations, then it will be through contributions to the positive feedback within the CMP circle (Fig. 2) whereby greater positive emotional experience and understanding of the local marine and coastal environment results in more citizens with sustained environmental values and pro-environmental behaviours [59].

A CMP provides an opportunity for a collective response to the condition of the city seascape. To support a deeper understanding of the coupled ecology of city and seascape, the CMP will play an active role in increasing marine literacy with positive consequences for sustainable development [60] (Fig. 3). A deeper understanding of the ecological patterns and processes, cultural heritage and ecosystem services associated with the city seascape and threats to seascape health and integrity will help communities make informed and responsible decisions for the future health of the city. To facilitate and co-create seascape knowledge, a strategic priority for the CMP should be to encourage and facilitate partnerships between academic institutions, community groups, marine-associated organisations and social enterprise to increase marine literacy, increase citizen science through local exploratory studies focused on enriching the understanding of the CMP ecosystem functions, their value and vulnerabilities. Public involvement in local seascape exploration and marine-focused projects will strengthen connections between people and the marine environment [61] and promote CMP citizenship. For example, beach activity (beach cleaning, rock pooling and walking activity) can lead to pro-environmental intentions and higher marine awareness [62]. A growing number of citizen science monitoring projects (e.g., Surfing for Science, Eye on the Reef, Sea Watch, Big Seaweed Search, MangroveWatch) are increasingly playing an important role in awareness raising, monitoring and contributing to marine policy [61, 63-66] suggesting great new potential for public engagement for cities hosting a CMP. In addition, participation in citizen monitoring projects can have emotional well-being benefits for volunteers, including improvements to mood (e.g., feeling happy, relaxed and calm), mental stimulation and feelings of enjoyment $[52,67]$.

The engagement activities of a CMP should start with efforts to educate school children and their families and examine opportunities for schools to conduct outdoor experiential learning. Storytelling is an effective mechanism for communicating complex information and 
motivating action and direct experience such as outdoor learning is a highly memorable experience and often results in a positive attitude towards the environment [48, 68, 69]. Even in coastal cities with marine research institutions, the local seascape is often underexplored and sometimes overlooked in terms of potential for local education and outreach. A CMP initiative can assess barriers to school children spending more learning time outside at the seaside and on the water and the feasibility of investing in a marine equivalent of the successful Forest Schools model (e.g., Beach Schools, Blue Schools) [70]. Learning initiatives should recognise that learning occurs at an individual, as well as at a range of collective levels (including organisations, networks and societal levels) [71]. A communications strategy including in-situ information and visitor guidance is essential to increase the level of public knowledge of the city seascape. Special attention should be directed to inform citizens of expected environmental changes such as sea-level rise and the associated risks from storminduced flooding and tsunamis. An ocean literate civic population will be better able to understand, anticipate and contribute to adaptation or mitigation strategies for climate change impacts and other environmental changes [72].

\subsection{CMP for enhanced community health and well-being}

Cities, and urbanisation in general, have been linked to many health problems, social deprivation, pollution, sedentary lifestyles and decreasing rates of contact with nature [73,74]. Consequently, there is a growing recognition of the role of nature-based policy and planning in counterbalancing some of the deleterious effects of living in cities with a renewed focus on transformative strategies to increase accessibility to urban 'blue spaces' (Box 1) for improved community health, well-being, and resilience $[75,76]$. The recognition of blue public spaces as community assets for healthy cities much like urban green spaces [77-80], places a CMP at the centre of efforts to improve physical and mental health and social cohesion in coastal cities.

There is growing evidence to suggest that contact with blue spaces, such as marine and coastal environments, may result in positive health gains [81], although this has been less explored for blue spaces than for green spaces [75].

i.) Physical activity. Recreational contact with marine and coastal environments is associated with the attainment of health-enhancing physical activity, coined the 'Blue Gym Effect' [82]. Research suggests that people living near the coast are less likely to be sedentary and more likely to report higher and recommended levels of physical activity [83,84]. Benefits are also observed for visits to these environments, including greater energy expenditure [56], and improved mental well-being [85], which may increase the length and quality of life and result in considerable healthcare cost savings [86]. 
ii.) Social contact. Public spaces, whether green spaces or blue spaces, have the potential to bring different communities together, and to enhance social contact [87]. For example, visits to the beach promote health and well-being and positive relationships with nature [88].

iii.) Stress reduction and happiness. Evidence suggests that people feel more restored (e.g. feeling calm, relaxed, revitalized and refreshed; [89,90], happier [91], more satisfied with their lives [92] and report better mental health when exposed to the coast [13,93]. In the city of Wellington, New Zealand, higher levels of blue space visibility (i.e., a sea view) were associated with lower psychological distress [16] suggesting that blue space, like green space, is important for both individual and community resilience.

Initial research suggests that the designation of marine and coastal areas (e.g., MPAs, national parks and nature reserves [94]; and urban interventions, which provide increased opportunities to interact with water and coastal features (e.g., coast paths; [76,95] may enhance the health benefits gained from marine and coastal environments. To optimise these socio-economic and health benefits, a CMP should review good practice and lessons learned in waterfront planning designed to increase accessibility, inclusivity and quality of enjoyment of park waters, coast and cultural heritage [96,98]. Consideration of how socio-political associations can influence blue space uses and behaviours [98] should also be a CMP priority. Relatively little is known about the seascape characteristics and processes that may imbue one blue space with more (or different) therapeutic seascape value when compared with another location $[99,100]$ and presents yet another key area of enquiry linking the city seascape of a CMP with its citizens.

\subsection{CMP branding for enhanced economic prosperity and sustainable business practice}

Evidence for economic boosting from coastal and marine park designations is welldocumented for designations such as World Heritage Areas where a positive effect on tourism, especially through increased overseas visitors and deepening place attachment has been documented [101-103]. In southwest England for example, economic impacts of the Jurassic Coast World Heritage designation are estimated at £103-119 million per annum (with up to 2,000 jobs created) helped by a high level of brand recognition and positive regard by visitors, businesses and residents [104]. Maritime heritage tourism, ecotourism and marine and coastal recreation would be at the heart of the activities which connect residents and visitors with the city seascape. Place branding techniques will be very important to the long-term sustainability of a CMP and have potential to drive a powerful transformative impact on blue urban policy and civic embrace of the seascape [105]. For example, largely due to branding and marketing, visitors and residents now recognise Hong Kong's marine parks as a more distinctive and unique resource than the city's green spaces [106]. 
Brand development strengthens the unique identity of a place, shapes perceptions and expectations, and has been successful in gaining competitive brand value for public parks $[106,107]$ and attracting investment. Tools such as place marketing can support the development of place identity and attachment. Parks with high brand identity engage emotions, evoke personal beliefs and prompt preferred behaviours [108]. To be effective, however, CMPs will first need to develop a very strong sense of what they wish to become, what they will offer and how they will function. With sufficient support and strong commitment to sustainable development, the CMP brand has the potential to elevate the global status of a city.

It is expected that elevated place status supported by place branding and social marketing to promote the unified vision for the CMP will form the inspirational catalyst for a network of community initiatives generating social, economic and environmental prosperity. For example, Park branding by the French National Parks have created a brand inspired by nature, "Esprit Parc National" (National Park Spirit), which helps promote local tourism services and products that meet the criteria of sustainable development and which contribute financially to the preservation of the natural and cultural heritage of the parks. Parc Naturel Regional D'Armorique (PNRA) established a Chartermark with a registered trademark for marketing local products (including seafood, earthenware, textiles, vegetables, sea salt, etc.) assisted by a business tourism marketing network resulting in the creation of more than a hundred small businesses in five years employing over 4,000 people. In Finland, the South Western Archipelago National Park (UNESCO Biosphere) successfully encouraged responsible tourism using voluntary cooperation agreements and codes of conduct between the Park and local businesses (e.g. fishing trips, tours, and accommodation providers) based on the principles of sustainable tourism development and stewardship of Park heritage.

A product developmental approach together with business strategy development, public opinion and branding surveys will be required to define and evaluate the perception, personality, value and expectations of the park brand. Collaborative marketing networks and associated collaborative technologies should be evaluated as an enabler for communitybased sustainable enterprise. Effective expression of core CMP values is critical to growing positive brand equity and sustainability [108] and is central to defining unique identity. Application of techniques such as Sustainable Market Orientation (SMO), where principles of sustainable development, corporate social responsibility and market orientation are integrated, have been effective at helping to balance environmental, social and economic strategies in the Fiordland National Park, New Zealand [109]. Integration of marketing and behaviour change techniques [42] will be key to ensure sustainable consumption and production patterns [110]. However, it is important to understand the barriers and the incentives that influence community movement towards a more holistic, integrated and 
sustainability-oriented business model, where goals are to achieve ecological, social and financial bottom lines (sometimes referred to as a 'triple-bottom line' [44,111,112].

Co-development and communication of CMP core values will be an important early task in the planning process and a program of socio-economic monitoring should be implemented to evaluate and understand impacts. In addition to the enhanced relationship with tourism and recreation, a CMP is well-placed in proximity to a city centre with infrastructure, industry and expertise to play an active role in support of innovations in sustainable maritime blue development through sustainable fisheries, aquaculture, biotechnology and renewable energy. Innovative, motivated and forward-looking social and environmental entrepreneurship where business ventures are designed with clear intent for economic, environmental and social purpose through harnessing the power of market-based approaches [113] are likely to be instrumental to the long-term success of a CMP. Furthermore, an emerging entrepreneurcentred stewardship culture increases the capabilities to attract government support and to generate earned-income [114]. It has been suggested that in certain conditions (e.g., high uncertainty, institutional inertia, low consensus on societal value, experimental freedom) entrepreneurs are likely to supplement, or surpass, the efforts of governments, NGOs and existing firms to achieve environmental sustainability by creating new markets, new information and more environmentally sustainable products, services and institutions [115].

\subsection{Embracing the cultural seascape}

For many people and communities in coastal cities, the sea has shaped their sense of identity, belonging, and connection [116]. Traditionally, fisher communities and seaports have been linked to feelings of sense of place and in defining the character of a place [117]. These 'blue roots' of the city, i.e. the cultural seascape, provide physical, psychological, and economic benefits [118] and will be an important consideration in defining the unique identity of a CMP and in the deepening connection between CMP and citizens. A distinctive sense of place usually occurs where a unique human-made identity, activity and vitality exists that is authentic to the location and crucial to the transformation of a CMP space into a meaningful and cherished place [119]. Maritime cultural heritage, for example, plays an important role in the multi-layered historical, social and political influences on place identity and community sense of place and should be understood and embraced by a CMP.

A CMP should have a role in safeguarding and educating the public about maritime cultural heritage where opportunities exist for a story to be told of human connection to the sea. For instance, a CMP would seek to honour and enable access to sacred spaces such as memorials to commemorate those lost at sea. In doing so, a CMP contributes to place making and also recognises that cultural heritage is an enabler of sustainable development through interaction with place identity, place meaning and attachment (the bonds people form with a 
place), factors that have also been positively linked to public participation and proenvironmental behaviour in coastal and marine parks [120-123].

Placing cultural awareness at the heart of the CMP designation enriches people's appreciation of seascapes and can inspire local pride and ownership of a CMP in a way that statutory biodiversity conservation designations with a narrower remit often fail to achieve [33]. The CMP should work with local historians to research and communicate maritime heritage stories and enrich the public knowledge of the region's cultural history and special place in history. Cultural history together with the environment underpin the spirit of place and an important role of a CMP is to provide a collective vision that encourages appreciation and celebration of this distinctive heritage. CMPs should increase the opportunities to engage, entertain and educate the public on marine and coastal themes through storytelling, film, theatre, and outdoor and underwater public art installations. The successful integration of art with public spaces can deliver a range of benefits including economic development, social cohesion, rejuvenation and tourism (e.g., Antony Gormley's Another Place, Grenada's underwater sculpture park, underwater museum in Cancún National Marine Park).

\subsection{CMP as part of an integrated land-sea urban planning system}

It is critical that a CMP adopts an holistic systems perspective that recognises the dynamic land-sea interconnectedness between people and coastal cities and how this shapes the city as a whole. The CMP concept recognises that people are a part of the city ecology and as such are inextricably linked in complex socio-ecological urban systems [124-126]. Connectivity is central to an holistic systems approach and important to understanding intrinsic and extrinsic relationships that influence the dynamic structure and function of a CMP and its integration within a host city. When considering the activities of the city itself, it is important to recognise that the sphere of influence of a coastal city extends seaward beyond the terrestrial waterfront. For instance, decisions on land use can have profound influences on the condition and value of the city seascape since they are often intimately linked to adjacent watershed condition through conduits to the sea such as rivers, waste water discharge and storm water runoff [127-130]. Often the condition of the city seascape is a consequence of land use activities occurring upstream in catchments some considerable distance from the sea. The quality of enjoyment and civic pride in a CMP will be influenced by the environmental condition of the seascape, particularly poor water quality and debris (e.g., plastic pollution) which can make water look uninviting, unhealthy and neglected and so undermine the psychological benefits of coastal environments [52]. Increased community use of marine areas through CMP designation amplifies the impetus for effective water quality management. As such, urban policymakers will need to transcend traditional paradigms in urban planning that often ignore the cross-boundary land-sea connectivity that has shaped coastal cities. 
The CMP can highlight the connection between land and sea and facilitate greater understanding of these inputs and potential threats from land-based activities. Addressing problems of runoff to rivers that impact the CMP should be looked upon as important opportunities for community partnership projects such as restoring riparian corridors and wetlands resulting in positive outcomes for downstream water quality [131]. CMP-enhanced community stewardship together with more sustainable and low impact business practices and city-wide initiatives to reduce land-based sources of pollution from entering the city seascape will address two SDG14 targets for marine ecosystem protection and restoration (Fig 3). Because of the typically degraded condition of the city seascape, including a strong restorative development agenda within the sustainable development mission of a city has potential to increase the quality and duration of community benefits linked to the city seascape.

\section{Marine park policy drivers and implementation}

A CMP is a highly collaborative community-centred entity supported by city policy and coordinated through a cross-sectoral local partnership working toward specific and diverse objectives consistent with best practices for sustainable coastal development. This paper outlines a set of broad potential themes aligned with global sustainable development goals within which inclusive local knowledge production, priority-setting and decision-making will need to identify site specific goals and objectives for a CMP. In addition to local policy drivers for sustainable cities, the key United Nations global policy drivers (adopted by 193 member states of the United Nations) that a CMP is expected to help address include SDG3 (Target 3.4); SDG8 (8.9); SDG10 (10.2); SDG11 (11.4 \& 11.7); SDG12 (12.2, 12.6, 12.8); SDG14 $(14.1,14.2 \&$ 14.A) and SDG17 (17.17) (Fig. 3). The CMP concept also addresses the New Urban Agenda goals for healthy cities and is likely to address many other national, regional and city-focused policy goals for transitioning coastal cities to healthier and sustainable city living.

Early in the evolution of a CMP, an exercise should be conducted with city-wide social and geographical inclusivity to determine if a CMP is desirable and to identify the range of benefits and concerns. If a CMP plan and business model are required then goals and strategies should be forward-looking, harmonised, synergistic and adaptive. Coherent urban policy for coastal cities transitioning to sustainability and enhanced city health and prosperity must integrate the city seascape. Consequently, the CMP should be valued as a key feature in the evolution and identity of the host city just as multifunctional green spaces are valued as part of the wider green infrastructure network [132]. To achieve these objectives, park planning should be integrated, or at least carefully coordinated, with city planning processes especially where decisions and strategic plans are likely to influence access to and condition of the CMP. The exact organisational structure and leadership for a city policy-based CMP will be 
determined by the location of the park and the bio-physical, cultural and political context. The organisational structure should encourage creative and innovative entrepreneurialism and engage a city's rich social capital. Social capital acts as a catalyst for progress through the stages of the coordination process [133].

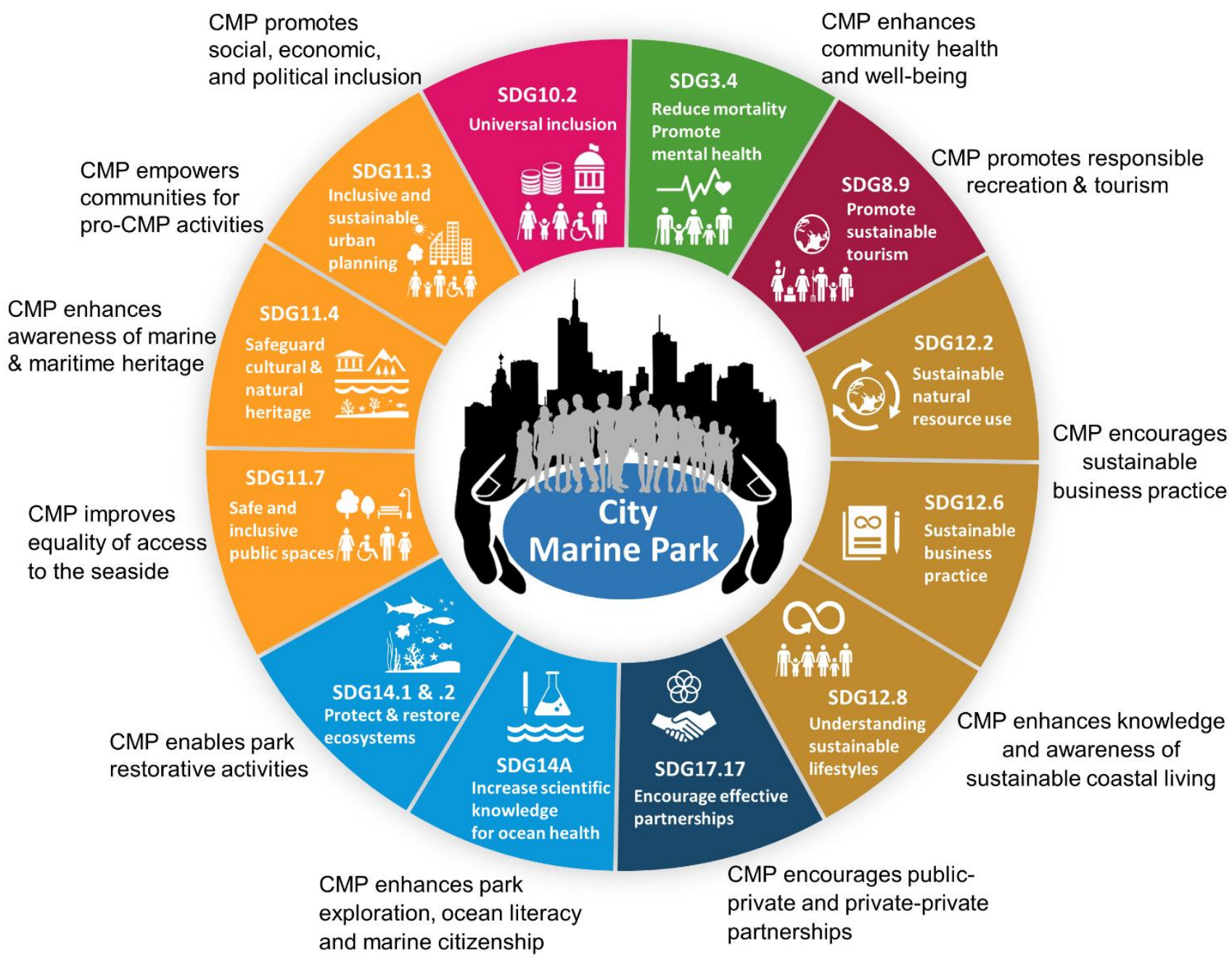

Fig. 3. City Marine Parks form a spatial nexus for addressing multiple interrelated Sustainable Development Goal (SDG) targets. Goal 3 is Good Health and Well-being; Goal 8 is Decent Work and Economic Growth; Goal 10 is Reduced Inequalities; Goal 11 is Sustainable Cities and Communities; Goal 12 is Responsible Consumption and Production; Goal 14 is Life Below Water and Goal 17 is Partnerships.

The CMP should grow into a diverse, complex and adaptive network of people, partnerships and projects that could be organised as a network of affiliated subsidiary groups (theme nodes) formed to coordinate activities that propel the CMP feedback circle through the four components: experience and understanding, value, care and enjoyment (Fig 2.). In this organisational model, CMP networks are independent, self-governed and self-managed 
entities coordinated by a core cross-sectoral team. Although a CMP originates as a nonstatutory entity, a city must decide if and how any existing or new regulatory instruments (e.g., primary and secondary legislation, licenses, concessions, etc.) can be woven into the CMP to help achieve objectives. A CMP will be complementary to existing statutory regulations and possibly could be used to extend existing statutory responsibilities of a city into the marine space if so designed. Any regulatory political interventions implemented will be case specific and cannot be adequately discussed here.

The CMP is likely to require financing and resources that exceed those available from civic budgets alone, requiring the investment from new and innovative financial mechanisms at multiple levels. Successful options for 'blue finance' include payments for ecosystem services, product sustainability labelling and public-private partnerships linked to tourism, conservation and the blue economy [134]. Because of its holistic approach, including a focus on enhancing economic prosperity, a CMP offers new low risk opportunities for the rapidly growing number of businesses interested in financial returns together with net positive social and environmental outcomes [134]. Additional investment opportunities will likely be associated with renewable energy installations and the recognition that marine ecosystems are effective carbon sinks. A CMP could provide opportunities for blue carbon financing mechanisms through corporations interested at looking for ways to reduce their carbon footprint [135].

\section{Discussion}

Coastal cities have a multiplicity of complex social and environmental sustainability challenges, yet also offer unique opportunities to enjoy benefits that flow from enhanced connectivity to the seascape and rich social capital. As gateways to the sea, coastal cities have a special evolutionary history where well-being, prosperity and the seascape are deeply interconnected. To advance towards sustainable development goals including the goal to make cities inclusive, safe, resilient and sustainable by 2030, coastal cities must enhance all aspects of their unique natural and social capital including adjacent marine spaces. The CMP concept is an ambitious, clear and overarching social initiative that is uniquely placed to encompass the interface between urban centres and the ocean providing opportunities to deliver progress for multiple sustainable development targets within a single holistic and community-centred vision. The CMP forms a spatial nexus for simultaneously addressing multiple interconnected global sustainable development targets with great potential for synergies and integration among multiple sectors. A nexus approach can also help detect harmful trade-offs and unexpected consequences and promote cooperation and coordination [136]. 
Coastal cities around the world are beginning to recognise the benefit to citizens of making their city seascape more healthy, inviting and accessible with safe and stimulating public spaces and cleaner waters suitable for swimming and other marine recreation. The striking juxtaposition between an industrial city waterfront, often with impaired coastal waters, and the perception of a marine park as fit only for healthy waters and low impact coastlines should not preclude the city seascape from being part of the progressive transitioning to a healthy city. In fact, the health of a city seascape should be one of the measures of success in progress toward the goal of a healthy, prosperous and sustainable coastal city exactly because of the integral role of the city seascape in the evolution and health of a coastal city.

Coastal cities are now starting to take responsibility for the health of coastal waters and seizing the opportunities for improved public access to explore, care for and enjoy the city seascape. This urban movement to embrace a city's connection to the sea, now referred to as 'blue urbanism' [137], promotes a healthier and celebratory connection between coastal cities and the seascape. The CMP concept outlines an innovative community-centred approach to support coastal cities in advancing toward a more harmonious and responsible relationship with the sea. A city community-led CMP is expected to encourage personal commitment, joint ownership, cooperation across stakeholders, better communication, greater inclusivity and the co-creation of a shared vision. Furthermore, coastal communities that are more closely integrated with the sea and are well-informed through marine literacy and transitioned to sustainable living will have a better chance of adapting to changing climate. We advocate a CMP as a tool in the climate change adaptation strategy for coastal cities. A greater understanding of the many benefits from a healthy and accessible city seascape and the key role played by a CMP in progress towards sustainable healthy city living will lead to the CMP being firmly embedded into the city, its institutions and the everyday life of individuals.

The co-creation and development of a CMP is not without major challenges, not least of which is the challenge of blending diverse community needs, financial constraints, defining the geographical scope of the CMP, establishing effective cross-sectoral collaboration and endurance of community interest.

There is still enormous unfulfilled potential for coastal cities around the world to deepen the knowledge and connection between people and the city seascape in a way that will bring positive socio-economic benefits, more inclusive participation and a boost to the health and well-being of city populations whilst simultaneously facilitating greater stewardship and revitalisation of the city seascape. The presence of industrial function (and characteristics such as pollution and poor accessibility) should not deter cities from the creation of a CMP. By encouraging sustainable business practice, increasing access and responsible use of the city seascape to satisfy people's needs locally, the CMP will make progress in addressing multiple sustainable development goals. Through storytelling and participation, a CMP can also help 
communicate the narrative and realised benefits of addressing SDGs. Even if the CMP does not offer statutory protection, by improving the city seascape for recreation a CMP can provide areas with greater capacity for high use thereby taking visitation pressure away from the most sensitive and vulnerable marine and coastal places.

A CMP will serve as a vehicle for building a deeper connection between people and the marine environment through a holistic approach where social, economic and cultural values and benefits are considered alongside the ecological health of the ecosystem. Through nurturing growth in local knowledge of marine and coastal ecosystem and heritage, the CMP aims to promote an organic growth in value, pride, enjoyment and care for the marine and coastal environment without the need for top-down exclusionary regulations. In contrast to conventional marine parks, the CMP initiative will not govern through enforced regulations and exclusionary measures. Instead, the CMP will focus resources to directly enable and empower individuals, communities and partnerships to undertake activities leading to the elevation of the city seascapes' role in civic identity and pride, enhanced community health, well-being, marine literacy and sustainable economic prosperity.

\section{References}

[1] C.J. Crossland, D. Baird, J.P. Ducrotoy, H. Lindeboom, R.W. Buddemeier, W.C. Dennison, B.A. Maxwell, S.V. Smith, D.P. Swaney, The coastal zone-a domain of global interactions, In: Crossland et al. (Eds.), Coastal fluxes in the Anthropocene, Springer, Berlin, Heidelberg, (2005), 1-37.

[2] R. von Glasow, T.D. Jickells, A. Baklanov, G.R. Carmichael, T.M. Church, L. Gallardo, C. Hughes, M. Kanakidou, P.S. Liss, L. Mee, L. R. Raine, Megacities and large agglomerations in the coastal zone: interactions between atmosphere, land, and marine ecosystems, Ambio 42(1) (2013) 13-28. https://doi.org/10.1007/s13280012-0343-9

[3] UN-DESA, United Nations, Department of Economic and Social Affairs, Population Division, 2017.

[4] The Sustainable Development Goals Report 2018, Issued by the Department of Economic and Social Affairs, United Nations, New York, United Nations Publications, ISBN 978-92-1-101390-0

[5] UN Habitat III Draft New Urban Agenda. United Nations Conference on Housing and Sustainable Urban Development, Surabaya, 2016. http://habitat3.org/wpcontent/uploads/Surabaya-Draft-New-Urban-Agenda-28-July-2016.pdf (accessed 06/10/2018)

[6] A.D. Tsouros, Twenty-seven years of the WHO European Healthy Cities movement: a sustainable movement for change and innovation at the local level. Health Promot Int. 30(Supp1) (2015) i3-i7. doi:http://dx.doi.org/10.1093/ heapro/dav046

[7] M. Kenzer, Healthy cities: a guide to the literature, Environment \& Urbanization, 115(2-3) (1999) 201-220. https://doi.org/10.1177/095624789901100103

[8] P.L. McCarney, Our Future: Sustainable Cities--Turning Ideas into Action, Working Papers id:556, eSocialSciences (2006). https://ideas.repec.org/p/ess/wpaper/id556.html

[9] R. Foley, T. Kistemann, Blue space geographies: Enabling health in place, Health \& Place 35 (2015)157-165. https://doi.org/10.1016/j.healthplace.2015.07.003 
[10] E. Andersson, S. Barthel, S. Borgström, J. Colding, T. Elmqvist, C. Folke, Å. Gren, Reconnecting cities to the biosphere: stewardship of green infrastructure and urban ecosystem services, Ambio 43(4) (2014) 445-453. https://doi.org/10.1007/s13280014-0506-y

[11] J.R. Wolch, J. Byrne, J.P. Newell, Urban green space, public health, and environmental justice: The challenge of making cities 'just green enough'. Landscape and Urban Planning 125 (2014) 234-244.

https://doi.org/10.1016/j.landurbplan.2014.01.017

[12] M. Grant, C. Brown, W.T. Caiaffa, A. Capon, J. Corburn, C. Coutts, CJ. Crespo, G. Ellis, G. Ferguson, C. Fudge, T. Hancock, R.J. Lawrence, M.J. Nieuwenhuijsen, T. Oni, S. Thompson, C. Wagenaar \& C. Ward Thompson, Cities and health: an evolving global conversation. Cities \& Health, 1(1) (2017) 1-9. https://doi.org/10.1080/23748834.2017.1316025

[13] M.P. White I. Alcock B.W. Wheeler, M.H. Depledge, Coastal proximity, health and well-being: Results from a longitudinal panel survey, Health \& Place 23 (2013c) 97 103. https://doi.org/10.1016/j.healthplace.2013.05.006

[14] M.E. Krasny, A. Russ, K.G. Tidball, T. Elmqvist, Civic ecology practices: Participatory approaches to generating and measuring ecosystem services in cities. Ecosystem Services 7 (2014) 177-186. https://doi.org/10.1016/j.ecoser.2013.11.002

[15] J. Finlay, T. Franke, H. McKay, J. Sims-Gould, Therapeutic landscapes and wellbeing in later life: Impacts of blue and green spaces for older adults, Health \& Place 34 (2015) 97-106. https://doi.org/10.1016/j.healthplace.2015.05.001

[16] D. Nutsford, A.L. Pearson, S. Kingham, F. Reitsma, Residential exposure to visible blue space (but not green space) associated with lower psychological distress in a capital city, Health \& Place 39 (2016) 70-78.

https://doi.org/10.1016/j.healthplace.2016.03.002

[17] L.R. Elliott, M.P. White, J. Grellier, S.E. Rees, R.D. Waters, L.E. Fleming, Recreational visits to marine and coastal environments in England: Where, what, who, why, and when? Marine Policy 97 (2018) 305-314.

https://doi.org/10.1016/j.marpol.2018.03.013

[18] C. Hein, Port cities and urban waterfronts: How localized planning ignores water as a connector, Wiley Interdisciplinary Reviews: Water 3(3) (2016) 419-438. https://doi.org/10.1002/wat2.1141

[19] T. Beatley, Blue Biophilic Cities. Nature and resilience along the urban coast, Series: Cities and the Global Politics of the Environment, Springer Nature, 2018.

[20] S. Fletcher, J. Potts, Ocean citizenship: an emergent geographical concept, Coastal Management 35(4) (2007) 511-524. https://doi.org/10.1080/08920750701525818

[21] J. Nahapiet, S. Ghoshal, Social capital, intellectual capital, and the organizational advantage, Academy of Management Review 23 (1998) 242-266.

https://doi.org/10.1016/B978-0-7506-7222-1.50009-X

[22] M.E. Krasny, K.G. Tidball, Civic ecology: a pathway for Earth Stewardship in cities, Frontiers in Ecology and the Environment 10(5) (2012) 267-273. https://doi.org/10.1890/110230

[23] F. Berkes, From community-based resource management to complex systems, Ecology and Society 11(1) (2006) 45. https://www.jstor.org/stable/26267815

[24] E. McKinley, S. Fletcher, Individual responsibility for the oceans? An evaluation of marine citizenship by UK marine practitioners, Ocean \& Coastal Management, 53(7) (2010), 379-384. https://doi.org/10.1016/j.ocecoaman.2010.04.012

[25] J.S. Gruber, Key principles of community-based natural resource management: a synthesis and interpretation of identified effective approaches for managing the commons, Environmental Management 45(1) (2010) 52-66. https://doi.org/10.1007/s00267-008-9235-y

[26] A. Curtis, H. Ross, G.R. Marshall, C. Baldwin, J. Cavaye, C. Freeman, A. Carr, G.J. Syme, The great experiment with devolved NRM governance: lessons from community engagement in Australia and New Zealand since the 1980s, Australasian 
Journal of Environmental Management, 21(2) (2014) 175-199.

https://doi.org/10.1080/14486563.2014.935747

[27] S. Gelcich, P. Buckley, J.K. Pinnegar, J. Chilvers, I. Lorenzoni, G. Terry, M. Guerrero, J.C. Castilla, A. Valdebenito, C.M. Duarte, Public awareness, concerns, and priorities about anthropogenic impacts on marine environments, Proceedings of the National Academy of Sciences, 111(42) (2014) 15042-15047.

https://doi.org/10.1073/pnas.1417344111

[28] H.K. Lotze, H. Guest, J. O'Leary, A. Tuda, D. Wallace, Public perceptions of marine threats and protection from around the world, Ocean \& Coastal Management 152 (2018) 14-22. https://doi.org/10.1016/j.ocecoaman.2017.11.004

[29] P. Timmerman, R. White, Megahydropolis: coastal cities in the context of global environmental change, Global Environmental Change 7(3) (1997) 205-234. https://doi.org/10.1016/S0959-3780(97)00009-5

[30] M. Mycoo, M.G. Donovan, A blue urban agenda: adapting to climate change in the coastal cities of Caribbean and Pacific Small Island Developing States, InterAmerican Development Bank, Washington, DC 20577, 2017. http://dx.doi.org/10.18235/0000690

[31] J. Day, N. Dudley, M. Hockings, G. Holmes, D. Laffoley, S. Stolton, S. Wells, Guidelines for applying the IUCN Protected Area Management Categories to Marine Protected Areas. Gland, Switzerland: IUCN, 2012

[32] IUCN WCPA, Applying IUCN's Global Conservation Standards to Marine Protected Areas (MPA). Delivering effective conservation action through MPAs, to secure ocean health \& sustainable development. Version 1.0. Gland, Switzerland, 2018.

[33] P. Christie, Marine protected areas as biological successes and social failures in Southeast Asia, in: J.B. Shipley (Ed.), Aquatic Protected Areas as Fisheries Management Tools: Design, Use, and Evaluation of These Fully Protected Areas, American Fisheries Society, Bethesda, Maryland, 42 (2004) 155-164.

[34] N.J. Bennett, P. Dearden, Why local people do not support conservation: Community perceptions of marine protected area livelihood impacts, governance and management in Thailand, Marine Policy 44 (2014) 107-116. https://doi.org/10.1016/j.marpol.2013.08.017

[35] T. Chaigneau, K. Brown, Challenging the win-win discourse on conservation and development: analyzing support for marine protected areas, Ecology and Society, 21(1) (2016). https://www.jstor.org/stable/26270340

[36] S. Giakoumi, J. McGowan, M. Mills, M. Beger, R. Bustamante, A. Charles, P. Christie, M. Fox, P. Garcia Borboroglu, S. Gelcich, P. Guidetti, P, Revisiting "success" and "failure" of marine protected areas: a conservation scientist perspective, Frontiers in Marine Science 5223 (2018).

https://doi.org/10.3389/fmars.2018.00223

[37] N.J. Bennett, Navigating a just and inclusive path towards sustainable oceans, Marine Policy 97 (2018) 139-146.

https://doi.org/10.1016/j.marpol.2018.06.001

[38] S.E. Rees, N.L. Foster, O. Langmead, S.J. Pittman, D.E. Johnson, Defining the qualitative elements of Aichi Biodiversity Target 11 with regard to the marine and coastal environment in order to strengthen global efforts for marine biodiversity conservation outlined in the United Nations Sustainable Development Goal 14, Marine Policy 93 (2018) 241-250. https://doi.org/10.1016/j.marpol.2017.05.016

[39] D. MacKinnon, C.J. Lemieux, K. Beazley, S. Woodley, R. Helie, J. Perron, J. Elliott, C. Haas, J. Langlois, H. Lazaruk, T. Beechey, Canada and Aichi Biodiversity Target 11: understanding 'other effective area-based conservation measures' in the context of the broader target, Biodiversity and Conservation 24(14) (2015) 3559-3581. https://doi.org/10.1007/s10531-015-1018-1

[40] D. Laffoley, N. Dudley, H. Jonas, D. MacKinnon, K. MacKinnon, M. Hockings, S. Woodley, An introduction to 'other effective area-based conservation measures' under Aichi Target 11 of the Convention on Biological Diversity: Origin, interpretation 
and emerging ocean issues, Aquatic Conservation: Marine and Freshwater Ecosystems 27 (2017) 130-137. https://doi.org/10.1002/aqc.2783

[41] N. Matz-Lück, J. Fuchs, The impact of OSPAR on protected area management beyond national jurisdiction: Effective regional cooperation or a network of paper parks? Marine Policy 49 (2014) 155-166. https://doi.org/10.1016/j.marpol.2013.12.001

[42] V.Y. Martin, B. Weiler, A. Reis, K. Dimmock, P. Scherrer, Doing the right thing: how social science can help foster pro-environmental behaviour change in marine protected areas, Marine Policy. 81 (2017) 236-246.

https://doi.org/10.1016/j.marpol.2017.04.001

[43] S. Michie, M.M. Van Stralen, R. West, The behaviour change wheel: a new method for characterising and designing behaviour change interventions, Implementation Science 6(1) (2011) 42.

[44] S.M. Reddy, J. Montambault, Y.J. Masuda, E. Keenan, W. Butler, J.R. Fisher, S.T. Asah, A. Gneezy, Advancing conservation by understanding and influencing human behaviour, Conservation Letters 10(2) (2017) 248-256. https://doi.org/10.1111/conl.12252

[45] A. Kollmuss, J. Agyeman, Mind the gap: why do people act environmentally and what are the barriers to pro-environmental behavior? Environmental Education Research 8(3) (2002) 239-260. https://doi.org/10.1080/13504620220145401

[46] E.R. Cetas, M. Yasué, A systematic review of motivational values and conservation success in and around protected areas, Conservation Biology 31(1) (2017) 203-212. https://doi.org/10.1111/cobi.12770

[47] J. Vince, B.D. Hardesty, Governance solutions to the tragedy of the commons that marine plastics have become, Frontiers in Marine Science 5 (2018) 214. https://doi.org/10.3389/fmars.2018.00214

[48] C. Kelly, 'I Need the Sea and the Sea Needs Me': Symbiotic coastal policy narratives for human wellbeing and sustainability in the UK, Marine Policy 97 (2018) 223-231. https://doi.org/10.1016/j.marpol.2018.03.023

[49] R.S. Friedman, E.A. Law, N.J. Bennett, C.D. Ives, J.P. Thorn, K.A. Wilson, How just and just how? A systematic review of social equity in conservation research, Environmental Research Letters 13(5) (2018) 053001. https://doi.org/10.1088/1748-9326/aabcde

[50] F. Boyd, M.P. White, S.L. Bell, J. Burt, Who doesn't visit natural environments for recreation and why: A population representative analysis of spatial, individual and temporal factors among adults in England, Landscape and Planning 175 (2018) 102113. https://doi.org/10.1016/j.landurbplan.2018.03.016

[51] C. Ward Thompson, P.A. Aspinall, Natural environments and their impact on activity, health, and quality of life, Applied Psychology: Health and Well-Being 3(3) (2011) 230-260. https://doi.org/10.1111/j.1758-0854.2011.01053.x

[52] K.J. Wyles, S. Pahl, K. Thomas, R.C. Thompson, Factors that can undermine the psychological benefits of coastal environments: Exploring the effect of tidal state, presence, and type of litter. Environment and Behavior 48(9) (2016) 1095-1126. https://doi.org/10.1177/0013916515592177

[53] P.A. Hansen-Ketchum, P. Marck, L. Reutter, E. Halpenny, Strengthening access to restorative places: Findings from a participatory study on engaging with nature in the promotion of health, Health \& Place 17(2) (2011) 558-571.

https://doi.org/10.1016/j.healthplace.2010.12.014

[54] J. Nyanjom, K. Boxall, J. Slaven, Towards inclusive tourism? Stakeholder collaboration in the development of accessible tourism, Tourism Geographies (2018) 1-23. https://doi.org/10.1080/14616688.2018.1477828

[55] D. Buhalis, S. Darcy, S., I. Ambrose, Best practice in accessible tourism: Inclusion, disability, ageing population and tourism, Channel View Publications, Bristol, 2012. 
[56] L.R. Elliott, M.P. White, A.H. Taylor, S. Herbert, Energy expenditure on recreational visits to different natural environments, Social Science \& Medicine 139 (2015) 53-60. https://doi.org/10.1016/j.socscimed.2015.06.038

[57] Keep Britain Tidy. 2018. News Release. http://www.keepbritaintidy.org/sites/default/files/resource/PR\%20$\% 20$ Coastal\%20Awards\%20announce.pdf

[58] V. del Rio, From downtown to the Inner Harbor: Baltimore's sustainable revitalization - Part 2: The Inner Harbor Plan (1967 to 2005), Focus 14(1) (2018) https://digitalcommons.calpoly.edu/focus/vol14/iss $1 / 17$

[59] P.T. Maiteny, Mind in the Gap: summary of research exploring 'inner' influences on pro-sustainability learning and behaviour, Environmental Education Research 8(3) (2002) 299-306. https://doi.org/10.1080/13504620220145447

[60] S. Dupont, G. Fauville, Ocean literacy as a key toward sustainable development and ocean governance, in: P. Nunes, L.E. Svensson, A. Markandya (Eds.), Handbook on the economics and management of sustainable oceans, Edward Elgar Publishers \& UNEP, Cheltenham, UK, 2017.

[61] D.C. McKinley, A.J. Miller-Rushing, H.L. Ballard, R. Bonney, H. Brown, S.C. CookPatton, D. M. Evans, R. A. French, J.K. Parrish, T.B. Phillips, S.F. Ryan, Citizen science can improve conservation science, natural resource management, and environmental protection, Biological Conservation 208 (2017) 15-28. https://doi.org/10.1016/j.biocon.2016.05.015

[62] K.J. Wyles, S. Pahl, M. Holland, R.C. Thompson, 2017b. Can beach cleans do more than clean-up litter? Comparing beach cleans to other coastal activities, Environment and Behavior, 49(5) (2017b) 509-535. https://doi.org/10.1177/0013916516649412

[63] A.I. Tulloch, H.P. Possingham, L.N. Joseph, J. Szabo, T.G. Martin, Realising the full potential of citizen science monitoring programs, Biological Conservation 165 (2013) 128-138. https://doi.org/10.1016/j.biocon.2013.05.025

[64] J.A. Cigliano, R. Meyer, H.L. Ballard, A. Freitag, T.B. Phillips, A. Wasser, Making marine and coastal citizen science matter, Ocean \& Coastal Management 115 (2015) 77-87. https://doi.org/10.1016/j.ocecoaman.2015.06.012

[65] S.E. Nelms, C. Coombes, L.C. Foster, T.S. Galloway, B. Godley, P.K. Lindeque, M.J. Witt, Marine anthropogenic litter on British beaches: a 10-year nationwide assessment using citizen science data, Science of the Total Environment 579 (2017) 1399-1409. https://doi.org/10.1016/j.scitotenv.2016.11.137

[66] A.J. Dean, E.K. Church, J. Loder, K.S. Fielding, K.A. Wilson, How do marine and coastal citizen science experiences foster environmental engagement? Journal of Environmental Management, 213, (2018) 409-416. https://doi.org/10.1016/j.jenvman.2018.02.080

[67] R.S. Koss, Y. Kingsley, Volunteer health and emotional wellbeing in marine protected areas, Ocean \& Coastal Management 53(8) (2010) 447-453. https://doi.org/10.1016/j.ocecoaman.2010.06.002

[68] J. Dillon, The benefits of engaging with nature through learning in natural environments, ECOS 35(2) (2014) 22-30.

[69] S. Pickering, Without walls: A discussion on the place of learning outdoors in primary schools in England, in: Reflections on Primary Geography, The Register of Research in Primary Geography (2017) 147-150. ISBN 978-0-9538154-5-6

[70] M. Mackintosh, Beach Schools in: S. Pickering (Ed.), Teaching Outdoors Creatively, Routledge, New York, 2017.

[71] A. Diduck, The learning dimension of adaptive capacity: Untangling the multi-level connections, in: D. R. Armitage \& R. Plummer (Eds.), Adaptive Capacity and Environmental Governance, Heidelberg: Springer, 2010, pp. 199-221.

[72] R. Shwom, C. Isenhour, R.C. Jordan, A.M. McCright, J.M. Robinson, Integrating the social sciences to enhance climate literacy, Frontiers in Ecology and the Environment 15(7) (2017) 377-384. 
[73] R. Godfrey, M. Julien, Urbanisation and health, Clinical Medicine 5(2) (2005) 137141. doi: $10.7861 /$ clinmedicine.5-2-137

[74] K. Srivastava, Urbanization and mental health, Industrial Psychiatry Journal 18(2) (2009) 75-76. https://doi.org/10.4103/0972-6748.64028

[75] S. Völker, T. Kistemann, The impact of blue space on human health and wellbeingSalutogenetic health effects of inland surface waters: A review, International Journal of Hygiene and Environmental Health 214(6) (2011) 449-460.

https://doi.org/10.1016/j.ijheh.2011.05.001

[76] J. Grellier, M.P. White, M. Albin, S. Bell, L.R. Elliott, M. Gascón, S. Gualdi, L. Mancini, M.J. Nieuwenhuijsen, D.A. Sarigiannis, M. van den Bosch, BlueHealth: a study programme protocol for mapping and quantifying the potential benefits to public health and wellbeing from Europe's blue spaces, British Medical Journal Open 7(6) (2017) e016188. doi: 10.1136/bmjopen-2017-016188

[77] WHO 2016. Urban green spaces and health: a review of evidence. Copenhagen: WHO Regional Office for Europe.

[78] M.P. White, I. Alcock, B.W. Wheeler, M.H Depledge, Would you be happier living in a greener urban area? A fixed-effects analysis of panel data, Psychological Science 24(6) (2013a) 920-928. https://doi.org/10.1177/0956797612464659

[79] M. van den Berg, W. Wendel-Vos, M. van Poppel, H. Kemper, W. van Mechelen, W. J. Maas, Health benefits of green spaces in the living environment: A systematic review of epidemiological studies, Urban Forestry \& Urban Greening 14(4) (2015) 806-816. https://doi.org/10.1016/j.ufug.2015.07.008

[80] R. Aerts, O. Honnay, O., A. van Nieuwenhuyse, Biodiversity and human health: mechanisms and evidence of the positive health effects of diversity in nature and green spaces, British Medical Bulletin 127(1) (2018) 5-22. https://doi.org/10.1093/bmb/ldy021

[81] M. Gascon, W. Zijlema, C. Vert, M.P. White, M.J. Nieuwenhuijsen, Outdoor blue spaces, human health and wellbeing: A systematic review of quantitative studies, International Journal of Hygiene and Environmental Health 220(8) (2017) 1207-1221. https://doi.org/10.1016/j.ijheh.2017.08.004

[82] M.P. White, S. Pahl, B.W. Wheeler, L.E.F. Fleming, M.H. Depledge, The 'Blue Gym': What can blue space do for you and what can you do for blue space? Journal of the Marine Biological Association of the United Kingdom, 96(1) (2016) 5-12. https://doi.org/10.1017/S0025315415002209

[83] A. Bauman, B. Smith, L. Stoker, B. Bellew, M. Booth, Geographical influences upon physical activity participation: evidence of a 'coastal effect', Aust. N. Z. J. Public Health 23 (1999) 322-324. https://doi.org/10.1111/j.1467-842X.1999.tb01265.x

[84] M.P. White, B.W. Wheeler, S. Herbert, I. Alcock, M.H. Depledge, Coastal proximity and physical activity: Is the coast an under-appreciated public health resource? Preventive Medicine 69 (2014) 135-140. https://doi.org/10.1016/j.ypmed.2014.09.016

[85] J. Thompson Coon, K. Boddy, K., Stein, R. Whear, J. Barton, M.H. Depledge, Does participating in physical activity in outdoor natural environments have a greater effect on physical and mental wellbeing than physical activity indoors? A systematic review, Environmental Science \& Technology, 45(5) (2011) 1761-1772. https://doi.org/10.1021/es102947t

[86] E. Papathanasopoulou, M.P. White, C. Hattam, A. Lannin, A. Harvey, A. Spencer, Valuing the health benefits of physical activities in the marine environment and their importance for marine spatial planning, Marine Policy 63 (2016) 144-152. https://doi.org/10.1016/j.marpol.2015.10.009

[87] V. Cattell, N. Dines, W. Gesler, S. Curtis, Mingling, observing, and lingering: Everyday public spaces and their implications for wellbeing and social relations, Health \& Place 14(3) (2008) 544-561. https://doi.org/10.1016/j.healthplace.2007.10.007

[88] K.J. Ashbullby, S. Pahl, P. Webley, M.P. White, The beach as a setting for families' health promotion: A qualitative study with parents and children living in coastal 
regions in Southwest England, Health \& Place 23 (2013) 138-147.

https://doi.org/10.1016/j.healthplace.2013.06.005

[89] M.P. White, S. Pahl, K. Ashbullby, S. Herbert, M.H. Depledge, Feelings of restoration from recent nature visits, Journal of Environmental Psychology 35 (2013b) 40-51. https://doi.org/10.1016/j.jenvp.2013.04.002

[90] K.J. Wyles, M.P. White, C. Hattam, S. Pahl, H. King, M. Austen, Are some natural environments more psychologically beneficial than others? The importance of type and quality on connectedness to nature and psychological restoration. Environment and Behavior (2017a). https://doi.org/10.1177/0013916517738312

[91] G. MacKerron, S. Mourato, Happiness is greater in natural environments. Global Environmental Change 23(5) (2013) 992-1000. https://doi.org/10.1016/j.gloenvcha.2013.03.010

[92] F. Brereton, J.P. Clinch, S. Ferreira, Happiness, geography and the environment, Ecological Economics 65(2) (2008) 386-396.

https://doi.org/10.1016/j.ecolecon.2007.07.008

[93] M.P. White, S. Pahl, B.W. Wheeler, M.H. Depledge, L.E. Fleming, Natural environments and subjective wellbeing: Different types of exposure are associated with different aspects of wellbeing, Health \& Place, 45 (2017) 77-84. https://doi.org/10.1016/j.healthplace.2017.03.008

[94] R. Bryce, K.N. Irvine, A. Church, R. Fish, S. Ranger, J.O. Kenter, J.O., Subjective wellbeing indicators for large-scale assessment of cultural ecosystem services, Ecosystem Services 21 (2016) 258-269. https://doi.org/10.1016/j.ecoser.2016.07.015

[95] L.E. Fleming, N. McDonough, M. Austen, L. Mee, M. Moore, P. Hess, M.H. Depledge, M. White, K. Philippart, P. Bradbrook, A. Smalley, Oceans and human health: a rising tide of challenges and opportunities for Europe, Marine Environmental Research 99 (2014) 16-19. https://doi.org/10.1016/j.marenvres.2014.05.010

[96] S. Kostopoulou, On the revitalized waterfront: Creative milieu for creative tourism, Sustainability 5(11) (2013) 4578-4593. https://doi:10.3390/su5114578

[97] World Health Organization. Healthier and happier cities for all. A transformative approach for safe, inclusive, sustainable and resilient societies. Copenhagen, Denmark, 2018. WHO Regional Office for Europe.

http://www.euro.who.int/_data/assets/pdf_file/0003/361434/consensuseng.pdf?ua $=1$ (last accessed 08/10/2018)

[98] F. Thomas, The role of natural environments within women's everyday health and wellbeing in Copenhagen, Denmark, Health \& Place 35 (2015) 187-195. https://doi.org/10.1016/j.healthplace.2014.11.005

[99] S.L. Bell, C. Phoenix, R. Lovell, B.W. Wheeler, Seeking everyday wellbeing: The coast as a therapeutic landscape, Social Science \& Medicine 142 (2015) 56-67. https://doi.org/10.1016/j.socscimed.2015.08.011

[100] S.L. Bell, B.W. Wheeler, C. Phoenix, C., Using geonarratives to explore the diverse temporalities of therapeutic landscapes: perspectives from "green" and "blue" settings, Annals of the American Association of Geographers 107(1) (2017) 93-108. https://doi.org/10.1080/24694452.2016.1218269

[101] Y.W. Su, H-L. Lin, Analysis of international tourist arrivals worldwide: the role of world heritage sites, Tourism Management 40 (2014) 46-58.

https://doi.org/10.1016/j.tourman.2013.04.005

[102] D. Wuepper, M. Patry, The World Heritage list: Which sites promote the brand? A big data spatial econometrics approach, Journal of Cultural Economics 41(1) (2017) 121. https://doi.org/10.1007/s10824-016-9266-9

[103] G.G. Gurney, J. Blythe, H. Adams, W.N. Adger, M. Curnock, L. Faulkner, T. James, N.A. Marshall, Redefining community based on place attachment in a connected world, Proceedings of the National Academy of Sciences 114(38) (2017) 1007710082. https://doi.org/10.1073/pnas.1712125114 
[104] Ash Futures. 2015 Dorset's Environmental Economy. Placing an economic value on the Jurassic Coast. Ash Futures.

http://www.dorsetaonb.org.uk/assets/downloads/Dorset_AONB_Partnership/JCWHSeconomy.pdf (accessed 05/10/2018)

[105] A.J. Wright, D. Veríssimo, K. Pilfold, E.C.M. Parsons, K. Ventre, J. Cousins, R. Jefferson, H. Koldewey, F. Llewellyn, E. McKinley, Competitive outreach in the 21st century: why we need conservation marketing, Ocean \& Coastal Management 115 (2015) 41-48. https://doi.org/10.1016/j.ocecoaman.2015.06.029

[106] C.S. Chan, M. Peters, L.M. Marafa, Public parks in city branding: Perceptions of visitors vis-à-vis residents in Hong Kong, Urban Forestry \& Urban Greening, 14(4) (2015) 1157-1165. https://doi.org/10.1016/j.ufug.2015.10.016

[107] G. Ashworth, G., The instruments of place branding: how is it done? European Spatial Research \& Policy 16(1) (2009) 9-22. https://doi.org/10.2478/v10105-0090001-9

[108] L.M. King, S.F. McCool, P. Fredman, E. Halpenny, Protected area branding strategies to increase stewardship among park constituencies, Parks 18(2) (2012) 54-63.

[109] R. Mitchell, Is physical activity in natural environments better for mental health than physical activity in other environments? Social Science \& Medicine 91 (2013) 130134. https://doi.org/10.1016/j.socscimed.2012.04.012

[110] Business and Sustainable Development Commission, Better Business, Better World, 2017. http://report.businesscommission.org.

[111] J.E. Stoddard, C.E. Pollard, M.R. Evans, The triple bottom line: A framework for sustainable tourism development, International Journal of Hospitality \& Tourism Administration 13(3) (2012) 233-258. https://doi.org/10.1080/15256480.2012.698173

[112] H. Breuer, K. Fichter, F. Lüdeke-Freund, I. Tiemann, Sustainability-oriented business model development: principles, criteria and tools, Int. J. Entrepreneurial Venturing, 10(2) (2018) 256-286.

[113] F. Wilson, J.E. Post, Business models for people, planet (\& profits): exploring the phenomena of social business, a market-based approach to social value creation, Small Business Economics 40(3) (2013) 715-737. https://doi.org/10.1007/s11187-011-9401-0

[114] S. Bacq, K.A. Eddleston, A resource-based view of social entrepreneurship: how stewardship culture benefits scale of social impact, Journal of Business Ethics (2017) 1-23. https://doi.org/10.1007/s10551-016-3317-1

[115] J.G. York, S. Venkataraman, The entrepreneur-environment nexus: Uncertainty, innovation, and allocation, Journal of Business Venturing, 25(5) (2010) 449-463. https://doi.org/10.1016/j.jbusvent.2009.07.007

[116] K. Gee, A. Kannen, R. Adlam, C. Brooks, M. Chapman, R. Cormier, C. Fischer, S. Fletcher, M. Gubbins, R. Shucksmith, R. Shellock, Identifying culturally significant areas for marine spatial planning, Ocean \& Coastal Management 136 (2017) 139147. https://doi.org/10.1016/j.ocecoaman.2016.11.026

[117] J. Urquhart, T. Acott, A sense of place in cultural ecosystem services: the case of Cornish fishing communities, Society \& Natural Resources 27(1) (2014) 3-19. https://doi.org/10.1080/08941920.2013.820811

[118] A. Hausmann, R.O.B. Slotow, J.K. Burns, E. Di Minin, The ecosystem service of sense of place: benefits for human wellbeing and biodiversity conservation, Environmental Conservation 43(2) (2016) 117-127. https://doi.org/10.1017/S0376892915000314

[119] K.J. Beidler, J.M. Morrison, J.M., Sense of place: inquiry and application. Journal of Urbanism: International Research on Placemaking and Urban Sustainability 9(3) (2016) 205-215. https://doi.org/10.1080/17549175.2015.1056210

[120] E.A. Halpenny, Pro-environmental behaviours and park visitors: The effect of place attachment, Journal of Environmental Psychology 30(4) (2010) 409-421. https://doi.org/10.1016/j.jenvp.2010.04.006 
[121] J. Tonge, M.M. Ryan, S.A. Moore, L.E. Beckley, The effect of place attachment on pro-environment behavioural intentions of visitors to coastal natural area tourist destinations, Journal of Travel Research 54(6) (2015) 730-743. https://doi.org/10.1177/0047287514533010

[122] T.M. Cheng, H.C. Wu, How do environmental knowledge, environmental sensitivity, and place attachment affect environmentally responsible behavior? An integrated approach for sustainable island tourism, Journal of Sustainable Tourism, 23(4) (2015) 557-576. https://doi.org/10.1080/09669582.2014.965177

[123] C.J. Wynveen, B.J. Wynveen, S.G. Sutton, Applying the value-belief-norm theory to marine contexts: Implications for encouraging pro-environmental behaviour, Coastal Management 43(1) (2015) 84-103. https://doi.org/10.1080/08920753.2014.989149

[124] E. Ostrom, A general framework for analyzing sustainability of social-ecological systems, Science 325(5939) (2009) 419-422. https://doi.org/10.1126/science.1172133

[125] C.D. Ives, D.J. Abson, H. Von Wehrden, C. Dorninger, K. Klaniecki, J. Fischer, Reconnecting with nature for sustainability, Sustainability Science 13(5) (2018) 1389-1397. https://doi.org/10.1007/s11625-018-0542-9

[126] F.W. Gatzweiler, S. Reis, Y. Zhang, S. Jayasinghe, Lessons from complexity science for urban health and well-being, Cities \& Health 1(2) (2018) 1-14. https://doi.org/10.1080/23748834.2018.1448551

[127] M. Beger, H.S. Grantham, R.L. Pressey, K.A. Wilson, E.L. Peterson, D. Dorfman, PJ Mumby, R. Lourival, D.R. Brumbaugh, H.P. Possingham, Conservation planning for connectivity across marine, freshwater, and terrestrial realms Biological Conservation 143(3) (2010) 565-575. https://doi.org/10.1016/j.biocon.2009.11.006

[128] J. Waterhouse, J. Brodie, S. Lewis, D.M. Audas, Land-sea connectivity, ecohydrology and holistic management of the Great Barrier Reef and its catchments: time for a change, Ecohydrology \& Hydrobiology 16(1) (2016) 45-57. https://doi.org/10.1016/j.ecohyd.2015.08.005

[129] K.L. Oleson, K.A. Falinski, D.M. Audas, S. Coccia-Schillo, P. Groves, L. Teneva, and S.J. Pittman, Linking Landscape and Seascape Conditions: Science, Tools and Management, in: S.J. Pittman (Ed.), Seascape Ecology, Wiley and Sons, London, 2017.

[130] C.S.S. Ferreira, R.P.D. Walsh, A.J.D. Ferreira, Degradation in urban areas, Current Opinion in Environmental Science \& Health 5 (2018) 19-25. https://doi.org/10.1016/j.coesh.2018.04.001

[131] J.D. Oppenheimer, S.K. Beaugh, J.A. Knudson, P. Mueller, N. Grant-Hoffman, A. Clements, and $\mathrm{M}$. Wight, A collaborative model for large-scale riparian restoration in the western United States, Restoration Ecology 23(2) (2015) 143-148. https://doi.org/10.1111/rec.12166

[132] R.C. Buckley, P. Brough, Economic value of parks via human mental health: an analytical framework, Front. Ecol. Evol. 5 (2017) 16. https://doi.org/10.3389/fevo.2017.00016

[133] R. Plummer, J. Fitzgibbon, People matter: The importance of social capital in the comanagement of natural resources, Natural Resources Forum, 30(1) (2006) 51-62. https://doi.org/10.1111/j.1477-8947.2006.00157.x

[134] N. Pascal, A. Brathwaite, T. Bryan, M. Philip, M. Walsh, Impact investment in marine conservation, Duke Environmental Law \& Policy Forum 28(2) (2018) 199-220. https://scholarship.law.duke.edu/delpf/vol28/iss2/1

[135] J. Howard, E. McLeod, S. Thomas, E. Eastwood, M. Fox, L. Wenzel, E. Pidgeon, The potential to integrate blue carbon into MPA design and management, Aquatic Conservation: Marine and Freshwater Ecosystems, 27 (2017) 100-115. https://doi.org/10.1002/aqc.2809

[136] J. Liu, V. Hull H.C. Godfray, D. Tilman P. Gleick, H. Hoff, C. Pahl-Wostl, Z Xu, M.G. Chung, J. Sun J, S. Li, Nexus approaches to global sustainable development, Nature Sustainability 1(9) (2018) 466. 
[137] T. Beatley, Blue Urbanism. Exploring connections between cities and oceans, Island Press, Washington DC, 2014. 